\title{
High-Efficiency 6" Multicrystalline Black Solar Cells Based on Metal-Nanoparticle-Assisted Chemical Etching
}

\author{
W. Chuck Hsu, ${ }^{1}$ Yen-Sheng Lu, ${ }^{2}$ Jung-Yi Chyan, ${ }^{3}$ and J. Andrew Yeh ${ }^{1}$ \\ ${ }^{1}$ Institute of Nanoengineering and Microsystems, National Tsing-Hua University, Hsinchu 30013, Taiwan \\ ${ }^{2}$ Department of Mechanical Engineering, Massachusetts Institute of Technology, Cambridge, MA 02139, USA \\ ${ }^{3}$ Sino-American Silicon Products Inc., Hsinchu 30077, Taiwan
}

Correspondence should be addressed to J. Andrew Yeh, jayeh@mx.nthu.edu.tw

Received 31 August 2011; Accepted 30 December 2011

Academic Editor: Junsin Yi

Copyright (C) 2012 W. Chuck Hsu et al. This is an open access article distributed under the Creative Commons Attribution License, which permits unrestricted use, distribution, and reproduction in any medium, provided the original work is properly cited.

\begin{abstract}
Multicrystalline silicon (mc-Si) photovoltaic (PV) solar cells with nanoscale surface texturing by metal-nanoparticle-assisted etching are proposed to achieve high power efficiency. The investigation of average nanorod lengths from $100 \mathrm{~nm}$ to $1 \mu \mathrm{m}$ reveals that the Si wafer decorated with $100 \mathrm{~nm}$ thick nanorods has optical reflection of $9.5 \%$ inferior than the one with $1 \mu \mathrm{m}$ thick nanorods $(2 \%)$. However, the short nanorods improve the doping uniformity and effectively decrease metal contact resistance. After surface passivation using the hydrogenated $\mathrm{SiO}_{2} / \mathrm{SiN}_{x}(5 \mathrm{~nm} / 50 \mathrm{~nm})$ stack, the minority carrier lifetime substantially increases from 1.8 to $7.2 \mu$ s for the $100 \mathrm{~nm}$-thick nanorod solar cell to achieve the high power efficiency of $16.38 \%$, compared with $1 \mu \mathrm{m}$ thick nanorod solar cell with $11.87 \%$.
\end{abstract}

\section{Introduction}

Solar energy is one of the green energy techniques and has drawn a lot of attention more than thirty years. In 2010, global photovoltaic (PV) solar cell production generated $20.5 \mathrm{GW}$ with a growth of $139 \% \mathrm{Y} / \mathrm{Y}$, compared with $9.86 \mathrm{GW}$ in 2009 [1]. PV solar cell industry becomes a fastgrowing energy generation technology in which crystalline silicon (c-Si) as the foundation stone takes the market share about $86.5 \%$, compared with the thin film products at $13.5 \%$ $[1,2]$. Multicrystalline Si (mc-Si) PV solar cells occupy $55.5 \%$ production while single crystalline $\mathrm{Si}$ (sc-Si) ones share $31 \%$. The main market trend in solar cells development involves a move toward to mc-Si solar cells due to the cheaper material and fabrication cost and potential application in remote and undeveloped regions where people eagerly need the supply of energy.

In order to increase the competitiveness of mc-Si solar cells, the solar power efficiency currently has to be improved for the replacement of fossil fuels, particularly via reduction of optical loss and eletrical loss. Antireflection (AR) coating plays a significant role on the enhancement of light absorption in the broadband spectrum range from near-UV to nearinfrared. Without proper AR treatment on the surface of the
c-Si solar cells, nearly $37 \%$ solar irradiation is reflected under terrestrial solar irradiation Air Mass 1.5 (AM 1.5) [3]. In the AR coating development of solar cells, the surface texturing techniques using micropyramids and subwavelength nanostructures are widely adopted for increasing light trapping on the Si solar cells [4-18]. Micropyramids with multilayers and graded-index AR coating have demonstrated to effectively reduce optical reflection in broad light spectrum, especially outside the visible band [6,7]. Nevertheless, AR coating materials such as silicon oxide $\left(\mathrm{SiO}_{2}\right)$ and silicon nitride $\left(\mathrm{SiN}_{x}\right)$ inevitably absorb sunlight to some degree, reducing light transmission to the underling $\mathrm{Si}$ substrate $[7,8]$. Subwavelength nanostructures have the characteristics of inherently excellent broadband antireflection properties (a low optical reflection of less than $5 \%$ in the wavelength range from 300 to $1000 \mathrm{~nm}$ ) and become a promising candidate for achieving a high poewer efficiency solar cell due to intensive suppression of optical loss. Several methods such as metal-nanoparticle (NP-) assisted etching [9-16], ICP etching [17-19], and electrochemical etching [20] have been proposed to fabricate Si nanostructures among which the cost-effective metal-NP-assisted etching emerges as a mainstream fabrication technique for texturing large-area $\mathrm{Si}$ wafers. 
At the present time, nanostructured solar cells do not have the high power efficiency as expected from the advantage of the excellent optical antireflection property. The nanostructures extruding from the silicon substance cause nonuniform distribution of dopants and influence the underlying $p-n$ junction, which lead to the large leakage current and degrade the cell performance. Besides, the numerous surface defects and dangling bonds at the ultrahigh surface area of Si nanostructures accelerate the combination of photogenerated minority carriers, limiting the power efficiency of nanostructured solar cells $[9,10]$. In this paper, the nanostructured silicon wafers (black silicon wafers, BSWs) are fabricated into PV solar cells based on metal-NP-assisted etching for increasing the broadband light trapping. The dimension of nanorods on black Si solar cells is investigated to achieve better $\mathrm{p}-\mathrm{n}$ junction property, lower contact resistance, and higher power efficiency. Besides, the $\mathrm{SiO}_{2} / \mathrm{SiN}_{x}$ stack is proposed to effectively passivate the nanostructured surface and simultaneously improve antireflectivity.

\section{Experimental Details}

$6^{\prime \prime}$ p-type (100) sc-Si and mc-Si solar wafers with thickness of $180 \mu \mathrm{m}$ and doping density of $10^{15} \mathrm{~cm}^{-3}$ were used to characterize the optical antireflection by texturing the surface using metal-NP-assisted etching. All Si wafers were treated by Piranha clean for $10 \mathrm{~min}$ and then rinsed by DI water for $10 \mathrm{~min}$. After cleaning, the silicon wafers were immersed into a Teflon bench containing metal-NP-assisted etching mixture at $20^{\circ} \mathrm{C}$. The etching mixture contains DI water/HF $(49 \%) / \mathrm{H}_{2} \mathrm{O}_{2}(30 \%) / \mathrm{AgNO}_{3}(0.1 \mathrm{M})$ with the volume ratio of $40: 20: 4: 1$. underetched for $18 \mathrm{~s}$ to $3 \mathrm{~min}$, the nanorods generate different lengths on the $\mathrm{Si}$ surface. The as-etched BSWs were cleaned by $\mathrm{H}_{2} \mathrm{NO}_{3}(79 \%)$ and $\mathrm{H}_{2} \mathrm{O}_{2}$ (31\%) to remove residual silver $(\mathrm{Ag})$ nanodendrites on the wafer surface. Some fabricated 6" BSWs were used for investigation on morphology, optical reflection, and carrier lifetime.

For the solar cell fabrication, n-type emitter was generated by doping the p-type silicon with phosphorus oxychloride $\left(\mathrm{POCl}_{3}\right)$ diffusion, forming a planar $\mathrm{p}$-n junction underlying the nanorods. The $\mathrm{POCl}_{3}$ diffusion was performed in a quartz tube with a temperature of $930^{\circ} \mathrm{C}$. The whole nanorods are ought to be $\mathrm{n}$ type after the diffusion. A diluted HF solution was used to remove the phosphosilicate glass (PSG) layer. The surface passivation of the BSWs using $\mathrm{SiO}_{2} / \mathrm{SiN}_{x}$ stack was performed as the following steps. Firstly, rapid thermal oxidation (RTO) was processed in a quartz furnace tube at $900^{\circ} \mathrm{C}$ for $15 \mathrm{~s}$. A $5 \mathrm{~nm}$-thick $\mathrm{SiO}_{2}$ was formed on the surface of the silicon nanorods as the intermediate layer. The deposition of a $50 \mathrm{~nm}$-thick $\mathrm{Si}_{3} \mathrm{~N}_{4}$ single layer was followed using high density plasma chemical vapor deposition (HDP-CVD; Duratek system Mutiplex Cluster $\mathrm{CVD}$ ) at $375^{\circ} \mathrm{C}$ with a pressure of $30 \mathrm{mTorr}$. The ion induced plasma (ICP) power was $850 \mathrm{~W}$ and the flow rate of processing gas of $\mathrm{SiN}, \mathrm{NH}_{3}$, and $\mathrm{SiH}_{4}$ was 75 , 24 , and $12 \mathrm{sccm}$, respectively. Hydrogenation of BSWs was performed using forming gas $\left(5 \% \mathrm{H}_{2}\right.$ and $\left.95 \% \mathrm{~N}_{2}\right)$ at $400^{\circ} \mathrm{C}$ for $30 \mathrm{~min}$. Thermal evaporation of $\mathrm{Al}$ on the back side was used to remove the parasitic $p-n$ junction via the built back side surface field. The front contact grids were screen-printed with a co-firing step. After the process, the fabricated black Si solar cells were used to perform electroluminescence (EL) and power conversion efficiency tests.

The morphology of the silicon nanostructures on the BSWs was observed by field-emission scanning electron microscopy (FESEM, Carl Zeizz, Ultra 55). Optical reflection of the BSWs was characterized using hemispherical reflection spectroscopy with a UV-Vis spectrometer (BWtek, BRC111A) and an integrated sphere (Ocean Optics, ISP 306-R). Effective carrier lifetime was obtained by microwave photoconductance decay ( $\mu$-PCD) technique (SEMILAB, WT-2000). Electroluminescence technique was used to measure the uniformity of doping. The characteristics of nanostructured Si solar cells were measured using Newport $1000 \mathrm{~W}$ class A solar simulator (91192A) with Keithley2400 source meter under AM 1.5 simulation $\left(100 \mathrm{~mW} / \mathrm{cm}^{2}\right.$ at $\left.25^{\circ} \mathrm{C}\right)$.

\section{Results and Discussion}

3.1. Morphology of Black Silicon Wafers. The morphology of silicon nanorods can be affected by either etching mixture concentration or etching time. Both sc-Si and mc-Si wafers were immersed in the etching mixture from $18 \mathrm{~s}$ to $3 \mathrm{~min}$ to form BSWs. Surface geometry of BSWs was analyzed by FESEM. Figure 1(a) shows the cross-sectional view of the (100) sc-BSW where the randomly distributed nanorods are perpendicular to the wafer surface, indicating the nanorods formed by metal-NP-assisted etching developing mainly along the $\langle 100\rangle$ direction. However, the length of nanorods is randomly distributed and not all the nanorods have the same length because some of the nanorods are laterally attacked by the subsequent supplement of Ag NPs and the violent Si etching under high concentration of HF (49\%). For mc$\mathrm{Si}$, the grains with intrinsic different crystalline orientations were also etched primarily along the $\langle 100\rangle$ direction, leaving the $\langle 100\rangle$ nanorods on the wafer. The nanorod direction is kept the same within one grain but changed abruptly when crossing the grain boundary as shown in Figure 1(b). These random nanorods have an average length of $1 \mu \mathrm{m}$ after etched for 3 min. Figure 1(c) shows that beign the Si nanorod array on $\mathrm{ms}$-Si has the average nanorod length about $100 \mathrm{~nm}$ after etched for $18 \mathrm{~s}$. From the measurement, $\mathrm{Si}$ in the metal-NPassisted etchant has an average etching rate of $0.33 \mu \mathrm{m} / \mathrm{min}$.

The experiment results show the metal-NPs assisted etching recipe developed by our group etches Si primarily along the $\langle 100\rangle$ direction. The etching mechanism is predominant by the $\mathrm{Ag}$ (catalyst) network formed via the deposition of Ag nanoparticles on the $\mathrm{Si}$ surface. $\mathrm{Ag}$ catalyses the etching behavior of $\mathrm{Si}$ underneath the $\mathrm{Ag}$ network primarily along two etching directions of $\langle 100\rangle$ and $\langle 110\rangle$, showing anisotropic etching [9-14]. However, Ag nanoparticles sometime penetrate through the protected mask region and spontaneously attacked the silicon substrate underneath the mask [10]. 


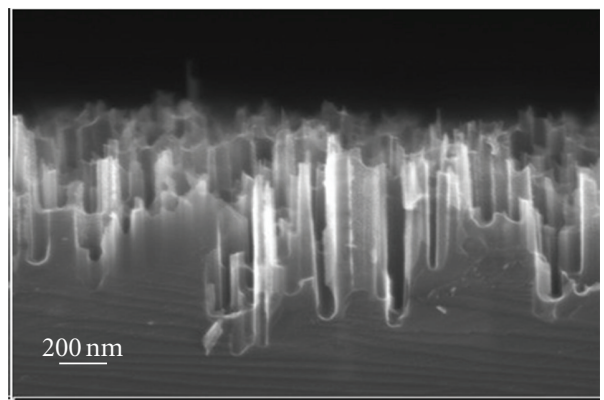

(a)

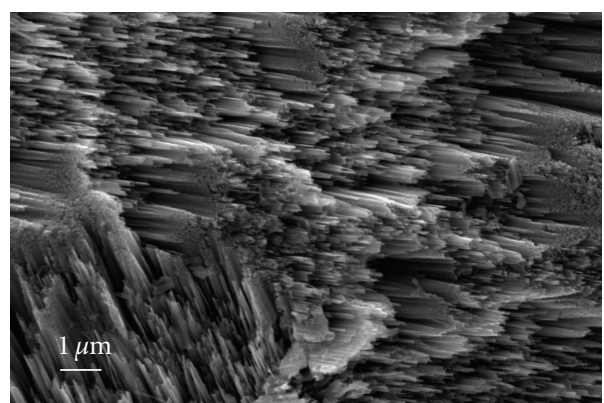

(b)

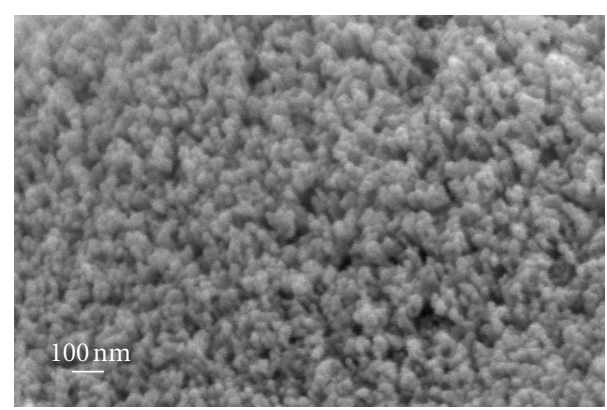

(c)

FIGURE 1: After metal-NP-assisted etching, the random size distribution of Si nanorods on black silicon wafers (BSWs) is averaged. (a) $600 \mathrm{~nm}$-thick nanorods formed on (100) silicon wafer. The orientation of nanorods is normal to the silicon surface, revealing that the anisotropic etching is primarily along $\langle 100\rangle$. (b) The nanorods built on grains with different crystalline orientations are clearly distinguished. The nanorods have the average length of $1 \mu \mathrm{m}$ after etched for $3 \mathrm{~min}$. (c) $100 \mathrm{~nm}$-thick nanorods on mc-BSW after $18 \mathrm{~s}$ etching.

3.2. Optical Reflection of Black Silicon Wafers. Reduction of optical reflection is considered a significant step to fabricate a high-efficiency solar cell because it would effectively decrease optical loss and increase the short-circuit current of solar cell. For mc-Si, each grain has distinct crystal orientations separated by the grain boundary, exhibiting different optical reflection in response to normal incidence. For as-cut $\mathrm{mc}-\mathrm{Si}$ wafer, the average optical reflection can be higher than $28 \%$.

The influence of nanorod length on the optical reflection of mc-BSWs was investigated in a broad spectrum from 400 to $1000 \mathrm{~nm}$. After metal-NP-assisted etching, the average length of nanorods distributed from $100 \mathrm{~nm}$ to $1 \mu \mathrm{m}$. For each mc-BSW, there was small deviation of optical reflection between grains due to intrinsic crystalline orientation. In Figure 2, the Si surface decorated with average $600 \mathrm{~nm}$-thick nanorods has the optical reflection varied from 5 to $4 \%$ (grain A and grain B). Some grains showed up as gray and some appeared as black. The color difference between grains can be easily distinguished by the naked eye. Therefore, there were five different points measured in order to obtain the average value of optical reflection for each BSW. The experimental results are shown in Figure 3. The reflection from BSWs is efficiently suppressed compared with the ascut solar wafer. The $100 \mathrm{~nm}$-thick nanorods reduced the optical reflection to $9.5 \%$ while the $1 \mu \mathrm{m}$-thick nanorods had the lowest optical reflection of $2 \%$. The optical reflection is approximately inversely proportional to the nanorod length. The excellent antireflection property may be attributed to the broadband antireflection of the fabricated subwavelength nanorods and the nonstopped adsorption of the incoming light after the multiple reflections in the long nanorods [21].

The BSWs with surface texturing using $100 \mathrm{~nm}$-thick, $600 \mathrm{~nm}$-thick, and $1 \mu \mathrm{m}$-thick nanorods were further fabricated into PV solar cells. In Figure 4, the $1 \mu \mathrm{m}$-thick nanorod mc-Si solar cell had considerably lower optical reflection of $2 \%$ from 400 to $1000 \mathrm{~nm}$, involving the visible light spectrum, which accounts for the dark black color observed by the naked eye. The grain boundary was hardly distinguishable due to the excellent light absorption, compared with the $100 \mathrm{~nm}$-thick nanorod PV cell. The color change indicates that the fabricated nanorods remarkably suppress the optical reflection of the solar wafer, which gives a potential to carry out the high efficiency solar cells.

3.3. Surface Passivation of Black Silicon Wafers. Nanostructured BSWs have the ultrahigh surface area compared with the as-cut silicon solar wafers and the micropyramid textured silicon solar wafers, which bring out more surface defect states and dangling bonds and aggravate the minority carrier trapping. The as-cut solar wafer had a carrier lifetime of $2.0 \mu \mathrm{s}$ while the $1 \mu \mathrm{m}$-thick nanorod BSWs had a shorter average carrier lifetime of $1.8 \mu$ s (see Table 1), which inevitably decrease the power efficiency due to the high surface recombination velocity of minorities in $\mathrm{Si}$ nanostructure [9-11].

It is of desire to develop a highly effective surface passivation layer with a low optical reflection that not only reduces the density of surface states but also leads to 


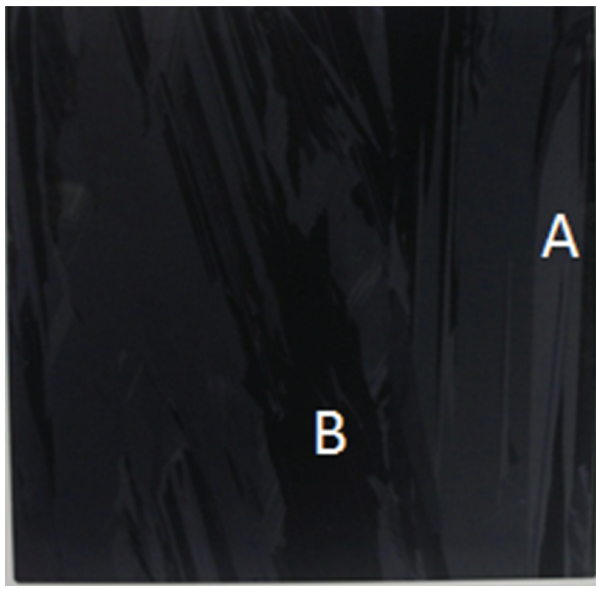

(a)

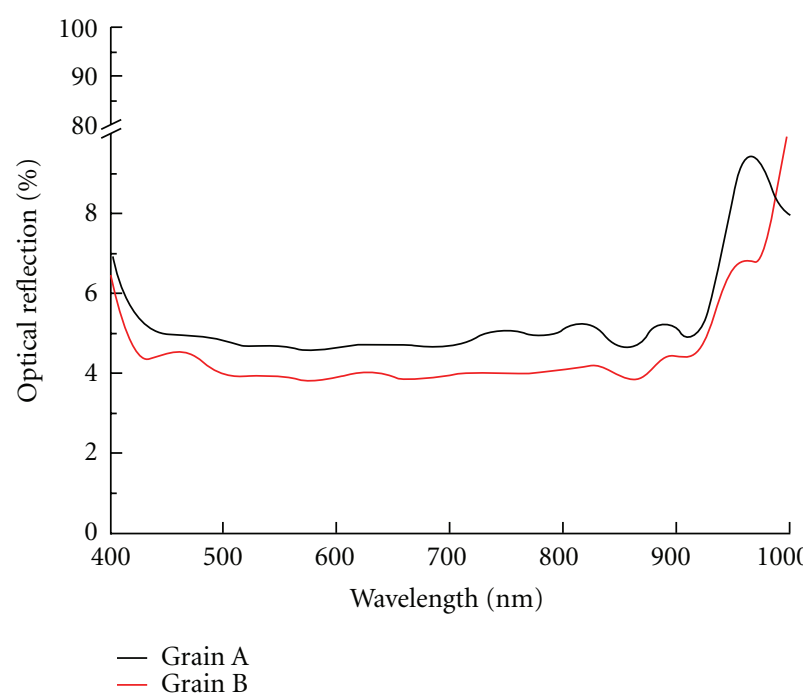

(b)

FIgURE 2: The optical reflection of $6^{\prime \prime}$ mc-BSW with surface texture of $600 \mathrm{~nm}$-thick nanorods. Each grain is easily distinguishable by the grain boundary and exhibits the different optical reflections. Two individual grains (grain A and grain B) show the average optical reflections of 5 and $4 \%$ in a broad spectrum from 400 to $1000 \mathrm{~nm}$.

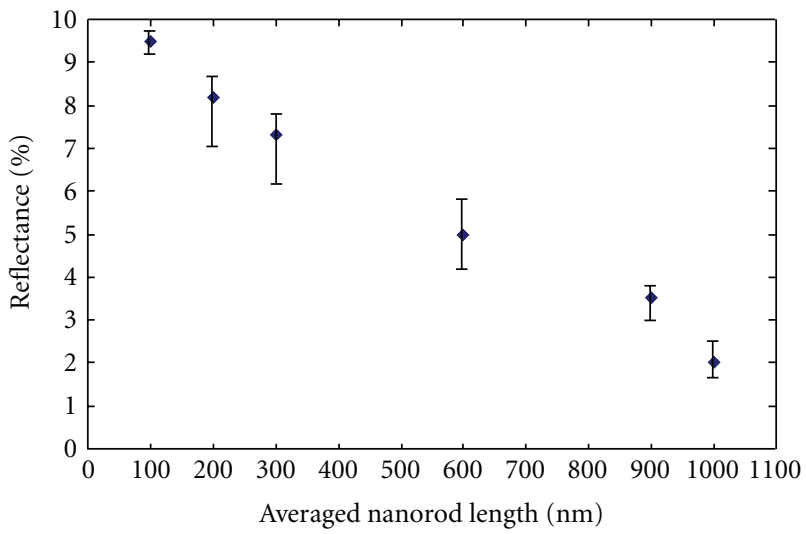

Figure 3: The optical reflection of $6^{\prime \prime}$ mc-BSWs with different nanorod lengths. The average length on BSWs distributes from 100 nm to $1 \mu \mathrm{m}$. The reflection is approximately inversely proportional to the average nanorod length. The reflection is about $9.5 \%$ for BSW decorated with $100 \mathrm{~nm}$-thick nanorods and suppressed to $2 \%$ for BSW with $1 \mu \mathrm{m}$-thick nanorods.

TABLE 1: Effective minority carrier lifetime of Si solar wafers.

\begin{tabular}{lc}
\hline Sample & Effective lifetime $(\mu \mathrm{s})$ \\
\hline As-cut & 2.0 \\
Black & 1.8 \\
Black $+\mathrm{SiO}_{2}+\mathrm{SiN}_{x}$ & 3.5 \\
Black $+\mathrm{SiO}_{2}+\mathrm{SiN}_{x}$ (hydrogenated) & 7.2 \\
\hline
\end{tabular}

high power efficiency on the nanostructured Si PV solar cells. The $\mathrm{SiO}_{2} / \mathrm{SiN}_{x}$ passivation stack with $\mathrm{SiO}_{2}$ as the intermediate layer is proposed to improve the conformity of the passivation layer on nanorods. The $5 \mathrm{~nm}$-thick $\mathrm{SiO}_{2}$ formed by rapid thermal oxidation (RTO) was firstly used to cover the whole surface of SiNWs and subsequently deposited with a layer of $50 \mathrm{~nm}$-thick $\mathrm{SiN}_{x}$ by PECVD. The black solar wafer with $\mathrm{SiO}_{2} / \mathrm{SiN}_{x}$ stack had the effective minority carrier lifetime of $3.5 \mu \mathrm{s}$. After further hydrogen passivation, the carrier lifetime substantially increased to $7.2 \mu$ s because the hydrogen atoms can penetrate into the defects to build the Si-H bonds, effectively decreasing the defect density. The hydrogenated $\mathrm{SiO}_{2} / \mathrm{SiN}_{x}$ stack passivation has the potential to realize the nanostructured PV solar cells with high power efficiency and used in for passivating the mc-Si PV solar cells.

3.4. Performance of Black Si PV Solar Cells. Nanostructured BSWs have the characteristics of excellent antireflection properties and become the promising candidate for achieving a high-efficiency PV solar cell. However, nanorods extruding from the silicon surface would cause the nonuniform distribution of dopants and influence the conformity of 


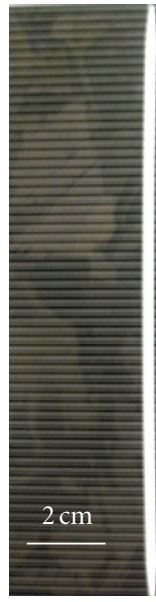

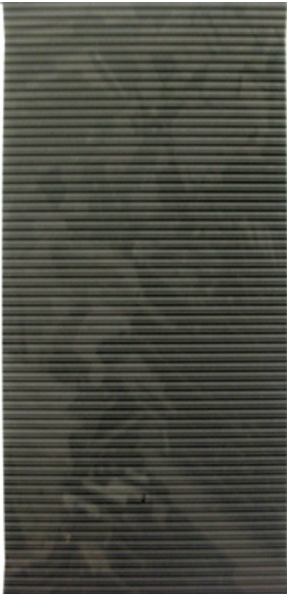

(a)
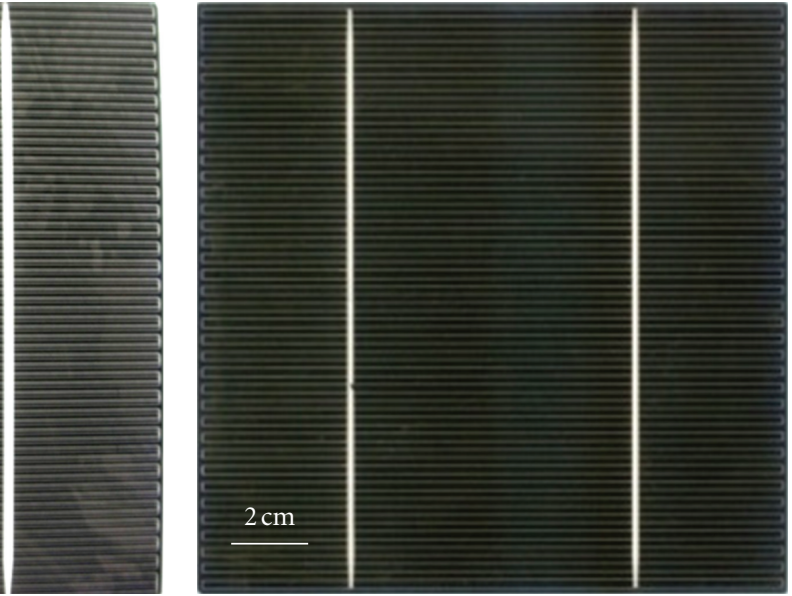

(b)

FIGURE 4: 6" mc-Si photovoltaic (PV) solar cells textured with average (a) $100 \mathrm{~nm}$-thick and (b) $1 \mu \mathrm{m}$-thick nanorods. The feature difference is remarkable for the two solar cells. The $1 \mu \mathrm{m}$-thick nanorods generate the dark black color easily recognized by the naked eye and the grain boundaries also become nondistinguishable compared with the solar cell with surface textured using 100 nm-thick nanorods.

TABLE 2: $I-V$ characteristic of black Si solar cells.

\begin{tabular}{|c|c|c|c|c|c|c|}
\hline Sample & $\eta(\%)$ & $V_{\mathrm{oc}}(\mathrm{mV})$ & $I_{\mathrm{sc}}\left(\mathrm{mA} / \mathrm{cm}^{2}\right)$ & $\mathrm{FF}(\%)$ & $R_{\mathrm{s}}(\mathrm{m} \Omega)$ & $R_{\mathrm{sh}}(\Omega)$ \\
\hline $0.1 \mu \mathrm{m}$ black Si solar cell & 16.38 & 624 & 36.1 & 76.2 & 2.84 & 35.82 \\
\hline $0.6 \mu \mathrm{m}$ black Si solar cell & 14.05 & 606 & 31.93 & 74.05 & 3.14 & 33.36 \\
\hline $1.0 \mu \mathrm{m}$ black Si solar cell & 11.87 & 588 & 31.8 & 66.32 & 4.67 & 18.05 \\
\hline
\end{tabular}

the underlying $\mathrm{p}-\mathrm{n}$ junction, which leads to the decrease of short circuit current $\left(I_{\mathrm{S}}\right)$ and the shunt resistance $\left(R_{\mathrm{sh}}\right)$ and degrades solar cell performance. Thus, BSWs with different average nanorod lengths $(100 \mathrm{~nm}, 600 \mathrm{~nm}$, and $1 \mu \mathrm{m})$ were fabricated into PV solar cells to investigate the length effect on solar cell performance. The current-voltage $(I-V)$ characteristics of nanostructured black Si solar cells were measured under a simulated AM 1.5 illumination condition at room temperature and the results are shown in Table 2.

The $1 \mu \mathrm{m}$-thick nanorod Si PV solar cells had the power efficiency $(\eta)$ of $11.87 \%$, the open-circuit voltage $\left(V_{\mathrm{oc}}\right)$ of $588 \mathrm{mV}$, short-circuit current density $\left(J_{\mathrm{sc}}\right)$ of $31.8 \mathrm{~mA} / \mathrm{cm}^{2}$, and fill-factor (FF) of 66.32. The large series resistance $\left(R_{\mathrm{s}}\right)$ of $4.67 \mathrm{~m} \Omega$ resulted from the poor electrical contact between screen-printed contact grids with the sharp and narrow nanorods led to the low FF and the smaller $\eta$. The small shunt resistance $\left(R_{\mathrm{sh}}\right)$ of $18.05 \Omega$ may be resulted from the nonuniform distribution of dopant below the nanorods. For the solar cells with short nanorods $(100 \mathrm{~nm})$, the performance factors of $\eta(16.38 \%), V_{\mathrm{oc}}(624 \mathrm{mV}), J_{\mathrm{sc}}\left(36.1 \mathrm{~mA} / \mathrm{cm}^{2}\right)$ and FF (76.2) are better than those of the $600 \mathrm{~nm}$-thick and $1 \mu \mathrm{m}$ thick nanorod solar cells. Besides, $R_{\mathrm{s}}$ decreased to $2.84 \mathrm{~m} \Omega$ due to the smoother short nanorods, which increases the contact conformity between metal and nanorods and reduces the voids existed in sharp nanostructures. $R_{\mathrm{sh}}$ of $35.82 \Omega$ is better than $600 \mathrm{~nm}$-thick and $1 \mu \mathrm{m}$-thick nanorod solar cell, indicating that the phosphors diffusion is uniformly distributed through the short nanorods and generates a good p-n junction.
PV solar cells with longer Si nanorod array have superior antireflection phenomenon but inevitably suffer from the nonuniformity of the dopant diffusion. The dopant uniformity was investigated by electroluminescence (EL) where EL applies a forward voltage and current on solar cell to generate localized irradiance in the near infrared (NIR) range of the spectrum due to carrier recombination. Figure 5 shows the EL image of solar cells with distinct nanorod lengths including $1 \mu \mathrm{m}, 600 \mathrm{~nm}$, and $100 \mathrm{~nm}$. The dark regions originated from the nonuniform distribution of dopant act as defects in solar cells, largely suppressing the electronto-photon conversion efficiency. The solar cell with longer nanorods $(1 \mu \mathrm{m})$ had the largest dark region and the lowest power efficiency (11.87\%). On the other hand, the $100 \mathrm{~nm}$ thick nanorod solar cell emitting the strong light intensity of NIR light from almost the sample surface had the superior power efficiency of $16.38 \%$.

A tradeoff between optical antireflection and diffusion uniformity of doping is strongly related to the length of the nanorod. Although short nanorods cannot suppress optical reflection as well as long nanorods [22], they characterized the good doping uniformity and decreased contact resistance. Furthermore, the surface passivation using $\mathrm{SiO}_{2} / \mathrm{SiN}_{x}$ stack intensively reduced the surface electron-hole recombination on the sidewall of the nanorods and contributed to the improvement of the power efficiency of black Si solar cells, compared with other nanostructured solar cells [9$11,13,14]$. 


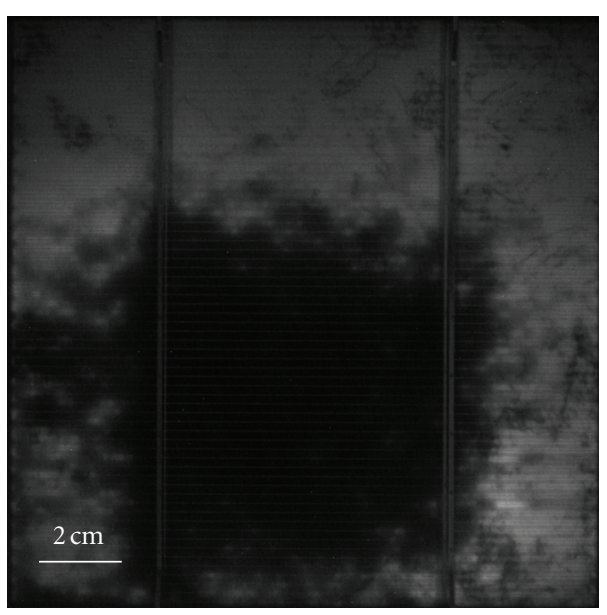

(a)

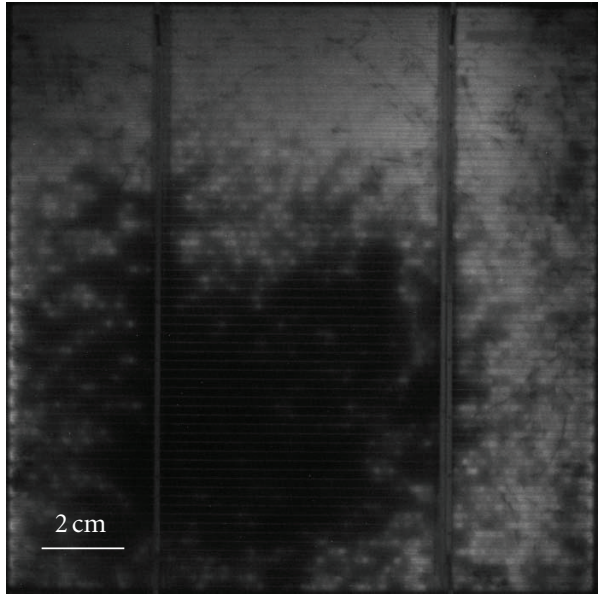

(b)

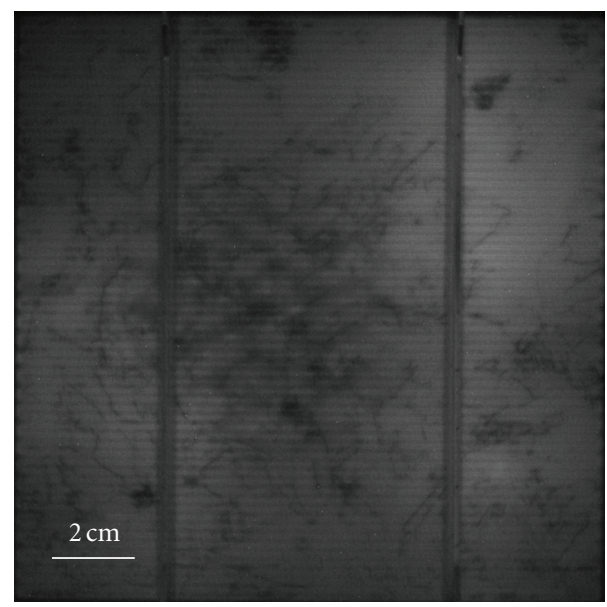

(c)

FIGURE 5: 6" mc-Si PV solar cells with surface texture using $1 \mu \mathrm{m}, 600 \mathrm{~nm}$, and $100 \mathrm{~nm}$-thick nanorods shown from (a) to (c) are tested by electroluminescence (EL) to investigate the doping uniformity in cells. The lateral nonuniform doping introduces defects (the dark regions) in solar cells, largely suppressing the minority carrier lifetime and the IR light irradiation. The solar cell decorated with $100 \mathrm{~nm}-$ thick nanorods has few dark areas, showing the better doping uniformity.

\section{Conclusion}

Solar cells with surface decoration using pyramids and nanorods have been widely used to improve the light absorption in substrate. However, there is a tradeoff between light trapping, contract resistance, and doping uniformity, reflecting the importance of determining the appropriate nanorod length on the black Si PV solar cells. 6" mcSi solar cell using $100 \mathrm{~nm}$-thick nanorod surface texturing has a power efficiency of $16.38 \%$ higher than the one with $1 \mu \mathrm{m}$-thick nanorod (11.87\%). Although the $100 \mathrm{~nm}$-thick nanorods have optical reflection of $9.5 \%$ inferior than the $1 \mu \mathrm{m}$-thick-nanorods (2\%), these short subwavelength structures improve doping uniformity, junction performance, and decrease contact resistance, leading to high power efficiency. The nanostructured solar cells have the same fabrication process as the commercial $\mathrm{Si}$ solar cells except for the metal-NP-assisted chemical etching. In the near future, the fabrication of surface nanostructures can be easily integrated into the industrial fabrication process and provides the competitiveness in providing mc-Si solar cells with high power efficiency.

\section{Acknowledgment}

The research was funded by National Science Council in Taiwan under project 100-2120-M-007-011-CC2. The authors are grateful for the research support from the SinoAmerican Silicon Products Incorporation and Instrument Technology Research Center (ITRC).

\section{References}

[1] http://www.solarbuzz.com/node/56.

[2] A. Goetzberger, C. Hebling, and H. W. Schock, "Photovoltaic materials, history, status and outlook," Materials Science and Engineering R-Reports, vol. 40, no. 1, pp. 1-46, 2003. 
[3] S. Chhajed, M. F. Schubert, J. K. Kim, and E. F. Schubert, "Nanostructured multilayer graded-index antireflection coating for Si solar cells with broadband and omnidirectional characteristics," Applied Physics Letters, vol. 93, no. 25, Article ID 251108, 3 pages, 2008.

[4] P. Campbell and M. A. Green, "Light trapping properties of pyramidally textured surfaces," Journal of Applied Physics, vol. 62, no. 1, pp. 243-249, 1987.

[5] T. Yagi, Y. Uraoka, and T. Fuyuki, "Ray-trace simulation of light trapping in silicon solar cell with texture structures," Solar Energy Materials and Solar Cells, vol. 90, no. 16, pp. 2647-2656, 2006.

[6] A. Premoli and M. L. Rastello, "Minimax refining of wideband antireflection coatings for wide angular incidence," Applied Optics, vol. 33, no. 10, pp. 2018-2024, 1994.

[7] M. Lipinski, A. Kaminski, J. F. Lelievre, M. Lemiti, E. Fourmond, and P. Zieba, "Investigation of graded index $\mathrm{SiO}_{\mathrm{x}} \mathrm{N}_{\mathrm{y}}$ antireflection coating for silicon solar cell manufacturing," Physica Status Solidi C, vol. 4, no. 4, pp. 1566-1569, 2007.

[8] H. Nagel, A. G. Aberle, and R. Hezel, "Optimized antireflection coatings for planar silicon solar cells using remote PECVD silicon nitride and porous silicon dioxide," Progress in Photovoltaics, vol. 7, no. 4, pp. 245-260, 1999.

[9] K. A. Peng, Y. Xu, Y. Wu, Y. J. Yan, S. T. Lee, and J. Zhu, "Aligned single-crystalline Si nanowire arrays for photovoltaic applications," Small, vol. 1, no. 11, pp. 1062-1067, 2005.

[10] H. Fang, Y. Wu, J. H. Zhao, and J. Zhu, "Silver catalysis in the fabrication of silicon nanowire arrays," Nanotechnology, vol. 17, no. 15, pp. 3768-3774, 2006.

[11] H. Fang, X. D. Li, S. Song, Y. Xu, and J. Zhu, "Fabrication of slantingly-aligned silicon nanowire arrays for solar cell applications," Nanotechnology, vol. 19, no. 25, Article ID 255703, 7 pages, 2008.

[12] J. Y. Chyan, W. C. Hsu, and J. A. Yeh, "Broadband antireflective poly-Si nanosponge for thin film solar cells," Optics Express, vol. 17, no. 6, pp. 4646-4651, 2009.

[13] C.-N. Chen, C.-T. Huang, C.-L. Chao, M. T.-K. Hou, W.C. Hsu, and J. A. Yeh, "Strengthening for sc-si solar cells by surface modification with nanowires," Journal of Microelectromechanical Systems, vol. 20, no. 3, pp. 549-551, 2011.

[14] W. C. Hsu, J. Y. Chyan, Y.-S. Lu, and J. A. Yeh, "Electroluminescence of out-of-plane silicon nanowire/silver oxide/silver nanodendrite heterostructures ," Optical Materials Express, vol. 1, no. 7, pp. 1210-1215, 2011.

[15] H. D. Um, J. Y. Jung, H. S. Seo et al., "Silicon nanowire array solar cell prepared by metal-induced electroless etching with a novel processing technology," Japanese Journal of Applied Physics, vol. 49, no. 4, Article ID 04DN02, 5 pages, 2010.

[16] D. Kumar, S. K. Srivastava, P. K. Singh, M. Husain, and V. Kumar, "Fabrication of silicon nanowire arrays based solar cell with improved performance," Solar Energy Materials and Solar Cells, vol. 95, no. 1, pp. 215-218, 2011.

[17] Y. F. Huang, S. Chattopadhyay, Y. J. Jen et al., "Improved broadband and quasi-omnidirectional anti-reflection properties with biomimetic silicon nanostructures," Nature Nanotechnology, vol. 2, no. 12, pp. 770-774, 2007.

[18] C. H. Sun, P. Jiang, and B. Jiang, "Broadband moth-eye antireflection coatings on silicon," Applied Physics Letters, vol. 92, no. 6, Article ID 061112, 3 pages, 2008.

[19] M. A. Tsai, P. C. Tseng, H. C. Chen, H. C. Kuo, and P. C. Yu, "Enhanced conversion efficiency of a crystalline silicon solar cell with frustum nanorod arrays," Optics Express, vol. 19, no. 1, pp. A28-A34, 2011.
[20] C. C. Striemer and P. M. Fauchet, "Dynamic etching of silicon for solar cell applications," Physica Status Solidi A, vol. 197, no. 2, pp. 502-506, 2003.

[21] Y. Kanamori, M. Sasaki, and K. Hane, "Broadband antireflection gratings fabricated upon silicon substrates," Optics Letters, vol. 24, no. 20, pp. 1422-1424, 1999.

[22] H. C. Yuan, V. E. Yost, M. R. Page, P. Stradins, D. L. Meier, and H. M. Branz, "Efficient black silicon solar cell with a densitygraded nanoporous surface: optical properties, performance limitations, and design rules," Applied Physics Letters, vol. 95, no. 12, Article ID 123501, 3 pages, 2009. 


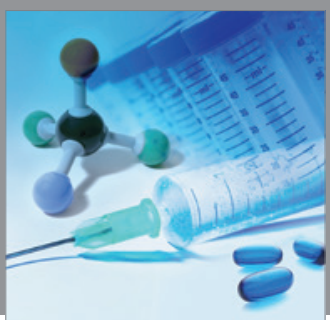

International Journal of

Medicinal Chemistry

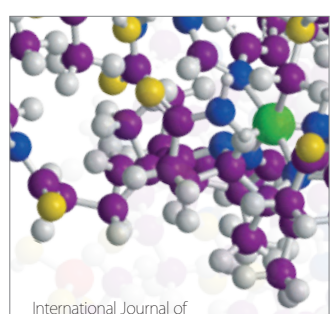

Carbohydrate Chemistry

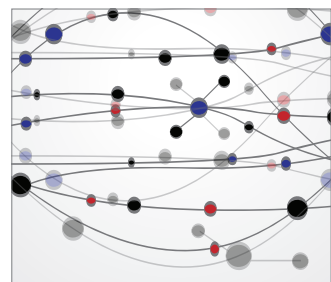

The Scientific World Journal
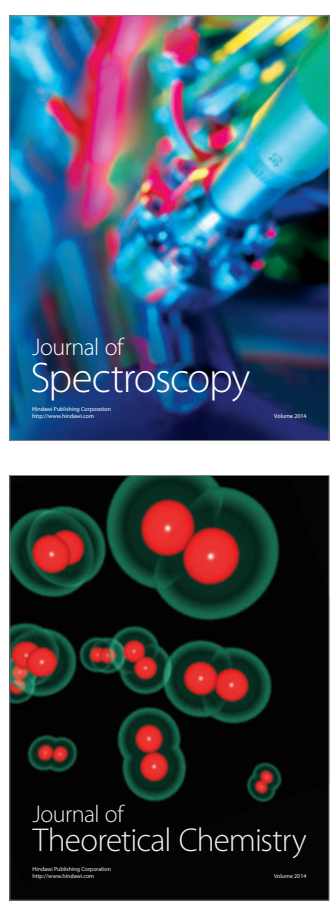
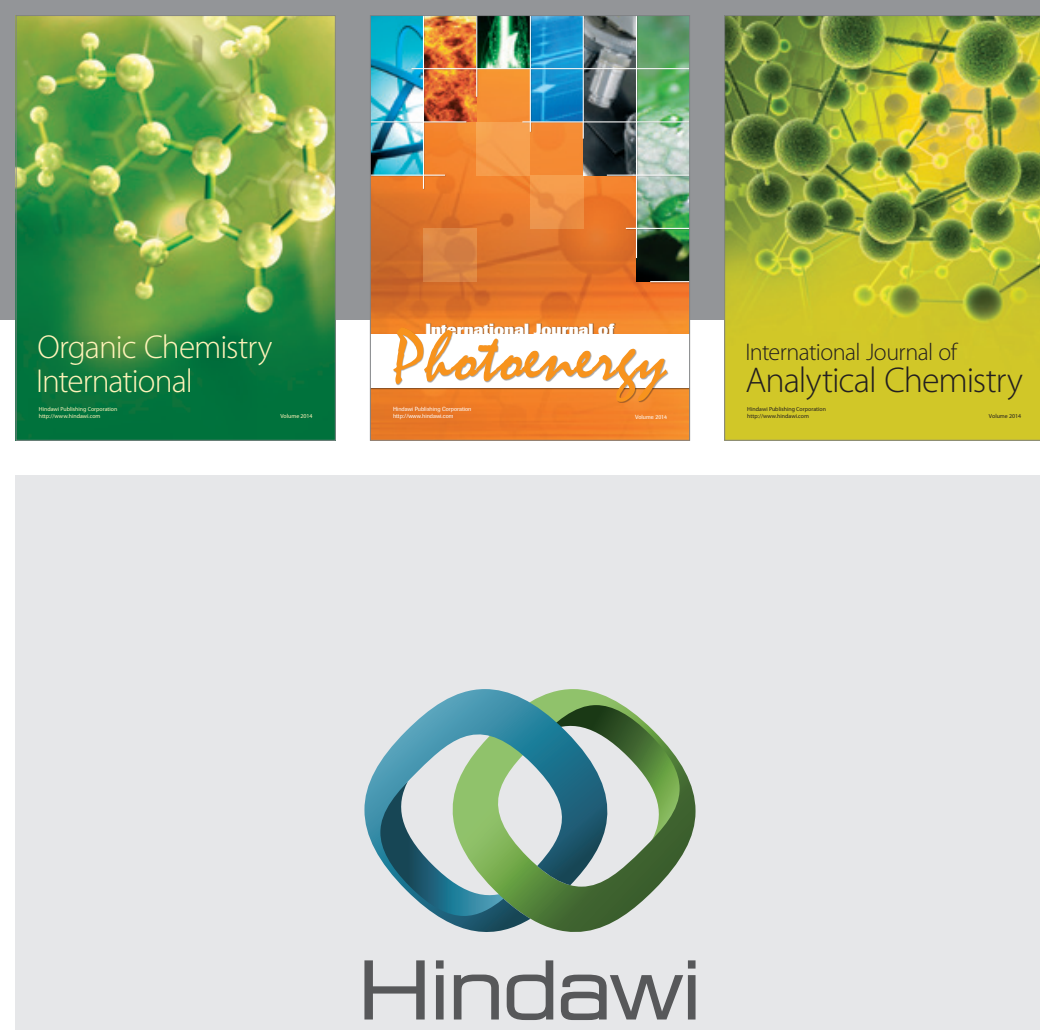

Submit your manuscripts at

http://www.hindawi.com
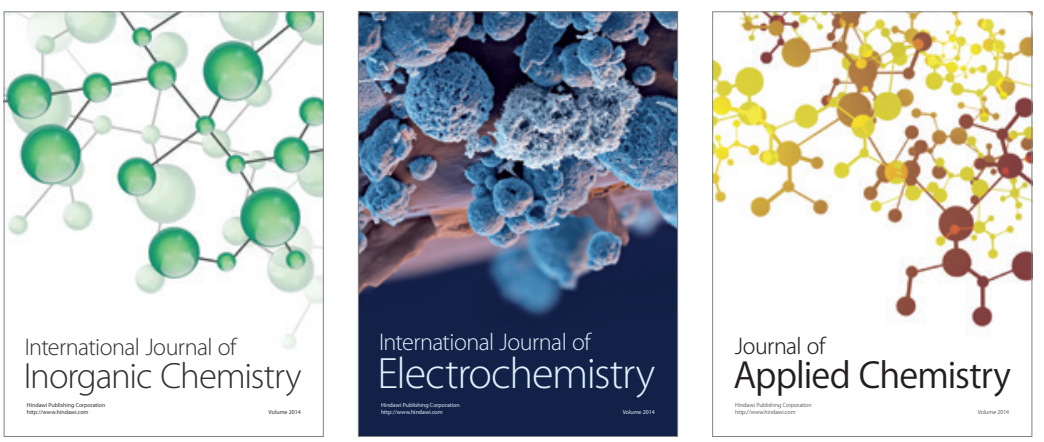

Journal of

Applied Chemistry
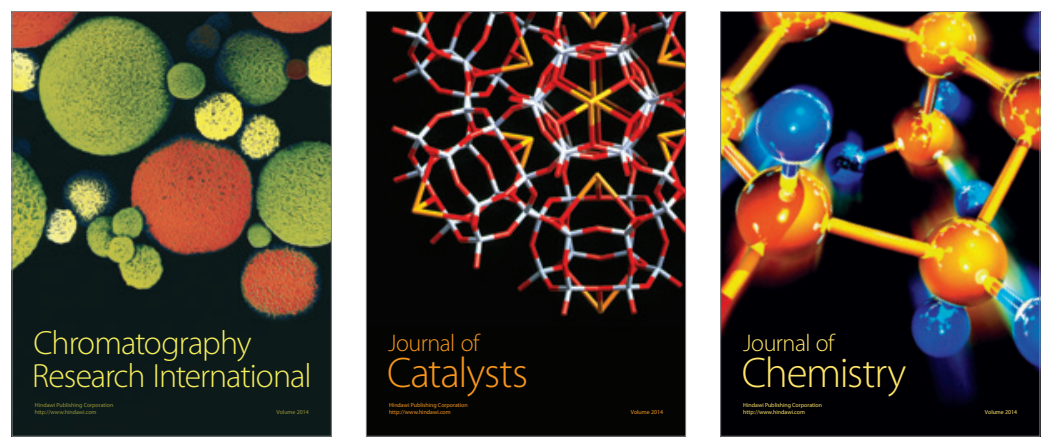
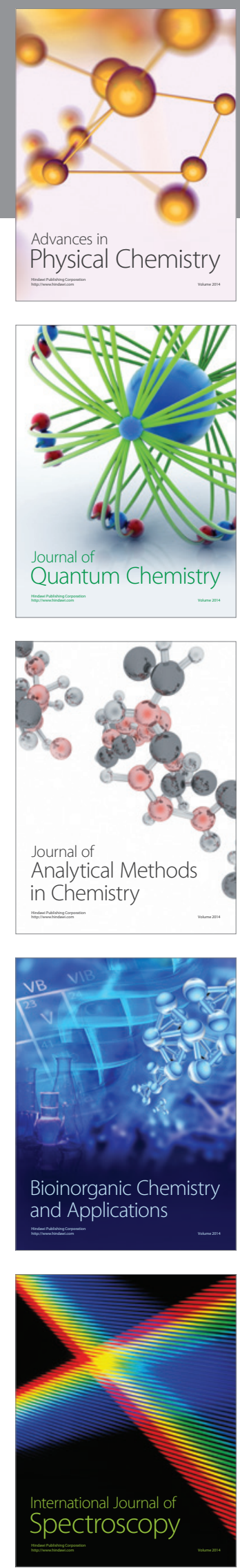